Session 3661

\title{
Interaction of Engineering Technology and Fine Arts through Instructor Collaboration
}

\author{
Andrew T. Rose, Valerie Grash \\ University of Pittsburgh at Johnstown
}

\begin{abstract}
Higher education strives to prepare graduates for career success and satisfaction in life. At the University of Pittsburgh at Johnstown (UPJ), most students prepare for their career through their major area of study by taking discipline specific courses in their major. To more fully develop their knowledge, University-wide general education (GenEd) requirements provide all UPJ students opportunities to develop competency in oral and written communication, quantitative reasoning skills, and a breadth of knowledge in social sciences, natural sciences and humanities. This last requirement is intended to expose students to diverse perspectives and personal enrichment opportunities. Although the GenEd curriculum requires students take courses in a variety of fields outside their major, the incorporation of activities that support the GenEd goals into discipline specific courses is encouraged. Similarly students in non-science and nonengineering majors can become better prepared for life and careers of the future through exposure to appropriate science and technology topics incorporated in their major courses. This paper discusses a collaborative effort by the authors incorporating a fine arts perspective in two civil engineering technology courses and a technical perspective in a fine arts course.
\end{abstract}

\section{Introduction}

Engineering education focuses on preparing students for careers in technology and the professional practice of engineering. Accreditation organizations, ${ }^{1}$ professional societies, ${ }^{2}$ as well as universities ${ }^{3}$ realize that in today's diverse world, engineering graduates need to be welleducated in areas beyond the typical technical knowledge necessary for engineering practice. As a result, exposure to and appreciation of the arts and humanities and the social sciences is a vital component in preparing engineering graduates who will better serve the needs of society. Although most universities attempt to accomplish this through a distribution of elective courses in the humanities and social sciences, connections between the technical content of the engineering curriculum and the values and paradigms of the humanities and social sciences are not typically developed or emphasized. Engineering students often do not appreciate their humanities and social science electives and have difficulty relating them to their education and career goals. In addition, incorporating additional liberal arts courses into an already crowded curriculum is difficult for many engineering and engineering technology programs. ${ }^{4}$ Similarly, students in the humanities, social sciences, and other non-science fields may not fully appreciate the influence of science and technology on their fields of study and careers. A recent trend at more and more universities is to offer courses introducing engineering to non-engineering majors as a way to improve the technical literacy of all students. 5

In an effort to improve engineering students' appreciation of the role of the arts and humanities in engineering design, as well as help non-engineering students gain an appreciation of the 
influence of technological developments on the arts and architecture, the authors collaborated to share their expertise and perspectives in the classroom by guest lecturing in each other's classes at UPJ. As an undergraduate college of the University of Pittsburgh, UPJ offers Bachelors degrees in the arts and humanities, sciences, education, business, and engineering technology. The enrollment is approximately 3000 students, the majority of which are from western and central Pennsylvania.

For the collaboration, the second author, Dr. Grash, made a highly visual presentation on Frank Lloyd Wright's Fallingwater in a civil engineering technology course on reinforced concrete design taught by the first author, Dr. Rose. A second presentation on the development of the skyscraper was given by Dr. Grash in a structural analysis class. In two sections of the Dr. Grash's fine arts class on Frank Lloyd Wright, Dr. Rose, made presentations on "Concrete, Cantilevers and Fallingwater," in which the development of reinforced concrete, cantilever behavior and the post-tensioning repair of Wright's masterpiece were discussed. Related student assignments, a field trip to Fallingwater, student feedback on the instructor exchange and suggested improvements are also discussed.

\section{Concept Development}

The idea for the collaboration originated several years ago when Dr. Rose was invited on a field trip to Fallingwater with Dr. Grash's Frank Lloyd Wright class. Guest lecturing on topics related to concrete design and architecture were considered as a starting point for the collaboration. The opportunity to collaborate took several years to develop since the Frank Lloyd Wright course is taught every other year and Dr. Rose only began teaching the reinforced concrete design course in the spring 2004 semester. This created the first opportunity for the interaction. Collaboration and interaction between the arts and engineering is supported by ABET, ${ }^{1}$ ASCE Policy 465 and its Body of Knowledge document, ${ }^{2}$ and UPJ GenEd program. ${ }^{3}$ ABET $^{1}$ requires engineering programs prepare well-educated graduates able to interact with other professionals in an increasingly complex and diverse world. In the Body of Knowledge document, ${ }^{2}$ ASCE is striving to raise the professional practice of civil engineering to a higher level. Sensing the diversity and complexity of the world in which future engineering professionals will work, engineering graduates must develop increased understanding of other fields and better appreciation for other perspectives and how they influence engineering decisions. ${ }^{2}$ At the University of Pittsburgh at Johnstown, the GenEd curriculum is intended to provide graduates from all disciplines the education needed for successful careers. In 2000 the General Education Working Group developed the following statement describing the purposes of the UPJ general education curriculum:

"The General Education Program at UPJ has been designed to prepare students to be creative, critical, and independent thinkers, capable of effective problem-solving and informed decision-making. Their education is characterized by both breadth of knowledge in diverse fields and depth of knowledge in focused areas of study as well as the development of fundamental competencies necessary for personal and professional growth. UPJ strives to produce graduates who appreciate learning, who inquire about and carefully evaluate the perspectives of others, and who are capable of responsible citizenship and the pursuit of intellectually satisfying, well-balanced lives."3 
In accordance with the UPJ GenEd program philosophy, the instructor collaboration described in this paper encourages a well-rounded education that provides engineering technology and nonengineering students exposure to and understanding of the perspectives of others.

\section{Concept Implementation}

The interaction between the two instructors took place in the spring 2004 semester and involved students in 4 classes. Dr. Grash prepared presentations for Dr. Rose's civil engineering technology courses in reinforced concrete design and advanced structures. Dr. Rose prepared a single presentation and presented it in two sections of Dr. Grash's fine arts class on Frank Lloyd Wright. The courses involved and number of students in each class are presented in Table 1.

Table 1 Summary of courses and students involved

\begin{tabular}{|l|c|c|c|}
\hline \multicolumn{1}{|c|}{ Course } & $\begin{array}{c}\text { Meeting } \\
\text { Time }\end{array}$ & $\begin{array}{c}\text { Course } \\
\text { Instructor }\end{array}$ & $\begin{array}{c}\text { Number of Students } \\
\text { Enrolled }\end{array}$ \\
\hline FA 0440 Frank Lloyd Wright & Day & Dr. Grash & 37 \\
\hline FA 0440 Frank Lloyd Wright & Night & Dr. Grash & 37 \\
\hline CET 1112 Reinforced Concrete Design & Day & Dr. Rose & 24 \\
\hline CET 1113 Advanced Structures & Day & Dr. Rose & 13 \\
\hline
\end{tabular}

Each course and the collaborative effort will now be discussed, followed by a summary of student feedback and comments.

FA 0440 Frank Lloyd Wright:

This course is a comprehensive study of master architect Frank Lloyd Wright, carefully examining his life, his career, and his ideas. Beginning with his unique family and childhood, the course chronologically explores those people and forces that influenced him, as well as closely studying his development as an architect. All of his major works are examined in detail, but, due to the geographical proximity of Fallingwater to UPJ, special attention is paid to his executed and unexecuted designs in western Pennsylvania, including a Saturday fieldtrip to Fallingwater. Most students taking this course (including several Engineering Technology students) did so to fulfill General Education ${ }^{3}$ requirements, although a couple students were Humanities majors with a concentration in Fine Arts. Although both the day and night classes had enrollments of over 35 students, on the days of Dr. Rose's presentations, less than 30 were in attendance and completed the evaluation form. The only difference in the composition of each class was that the evening class had more returning adult students and more Engineering Technology students than the day course. Otherwise, the course requirements and content were identical.

Although Dr. Grash had taught this course several times previously, an exchange of lectures between the two disciplines had not been done before. Thus, the first decision to be made was when during the semester to make the exchange. For practical purposes, the best solution for the Frank Lloyd Wright class seemed to be late in the semester, during the week the history, structure and repair of Fallingwater were covered and right before the field trip to the house. Naturally, this would better prepare the students for what they were about to see during the onsite visit. For the day class, the entire period was devoted to Dr. Rose's presentation. The night class meets once a week for three hours. In this case, Dr. Rose's presentation occurred in 
the second half of the class period after Dr. Grash had covered material on Fallingwater, in preparation for the field trip.

For the presentation, Dr. Rose chose to discuss three topics related to Fallingwater. The first topic presented was a brief history of Portland cement concrete, concrete strength and behavior, and the use of reinforcing steel in concrete. The second topic presented was cantilever beam behavior. This was accomplished using visual images of cantilever beams in nature, such as rock overhangs and trees subject to wind loading. These were intended to help students with non-technical backgrounds relate to the concepts discussed. The third topic focused on the structural system used in Fallingwater, the excessive deflections of the cantilevers, and the posttensioning repairs to the main cantilever beams in the structure. To enhance the presentation, physical models were used to illustrate concepts such as brittle vs. ductile behavior, beam bending and the corresponding tension and compression surfaces in beams, and how the posttensioning was used to repair the cantilever beams.

To help prepare for the portion of the presentation on the repairs to Fallingwater, Dr. Rose had students in his reinforced concrete design class prepare papers as an extra credit assignment. Most students in the class took advantage of the assignment. Papers were prepared on topics such as the original design and construction of Fallingwater, the monitoring of cracks and movements and the repairs to the structure. Other students researched related topics, such as creep in concrete, post-tensioning of concrete, and several chose to build models showing cantilever and simply supported beam behavior. These extra credit assignments and the references they provided greatly assisted Dr. Rose in preparing for the presentation in the Frank Lloyd Wright (FLW) class.

Students evaluated the presentation titled "Concrete, Cantilevers, and Fallingwater" and the results are summarized for both the day and night classes in Table 2.

Table 2 Summary of student feedback regarding Dr. Rose's presentation in the FLW classes

\begin{tabular}{|l|c|c|}
\hline \multicolumn{1}{|c|}{ Evaluation Statement } & \multicolumn{2}{c|}{ Average Response } \\
\cline { 2 - 3 } & Day Class & Night Class \\
\hline $\begin{array}{l}\text { The amount I learned (that I already did not know) about concrete, } \\
\text { cantilever beams and the repairs to Fallingwater was: } \\
\text { (1 nothing }-5 \text { significant) }\end{array}$ & 4.1 & 3.4 \\
\hline $\begin{array}{l}\text { The presentation was at the right level and easy to follow: } \\
\text { (1 strongly disagree }-5 \text { strongly agree) }\end{array}$ & 4.1 & 4.0 \\
\hline $\begin{array}{l}\text { The presentation gave me an appreciation of the engineering } \\
\text { considerations and constraints for the repair of Fallingwater's } \\
\text { defelecting terraces: } \\
\text { (1 strongly disagree }-5 \text { strongly agree) }\end{array}$ & 4.4 & 3.9 \\
\hline $\begin{array}{l}\text { I think it would be beneficial to have more opportunities for } \\
\text { interdisciplinary topics and guest speakers in this or other technical } \\
\text { courses: } \\
\text { (1 strongly disagree - 5 strongly agree) }\end{array}$ & 4.5 & \\
\hline
\end{tabular}


Student evaluations demonstrated strong approval for the content and presentation of Dr. Rose's lecture. One student pointedly mentioned how well Dr. Rose's simple demonstrations with balsa wood and steel rods explained the cantilever behavior and the properties of concrete reinforced with steel. Most students felt this hands-on approach and Dr. Rose's clearly articulated explanations of engineering terms and processes added significantly to their appreciation for and understanding of Fallingwater. Evaluations were slightly lower for the evening class, although it should be noted again that there were a greater number of engineering students in that class (thus, they felt familiar with the material already, and rather smugly believed that certain aspects of the presentation were "beyond arts students' knowledge"). Moreover, as always, once a week evening classes are a challenge to maintaining students' interest, particularly when the lights go out for a PowerPoint presentation.

\section{CET 1112 Reinforced Concrete Design:}

This course introduces civil engineering technology students to reinforced concrete behavior and design, in accordance with the American Concrete Institute's (ACI) Building Code Requirements for Structural Concrete. The course includes considerable coverage of design of basic structural elements such as beams, short and slender columns, footings, and retaining walls. The course is a 4-credit, required course, usually taken in the junior year. The class structure consists of 3 onehour class periods and a three-hour recitation period each week. The class consisted of 24 students who have all taken the required prerequisite mechanics courses and have usually completed a structural steel design course the prior semester.

Dr. Grash's PowerPoint presentation, “Fallingwater and Frank Lloyd Wright's Reinforced Concrete Aesthetics" focused on two main issues: (1) a brief history of Wright's use of reinforced concrete; and (2) his specific use of it at Fallingwater, concentrating on the aesthetic use of the material. The lecture began with a discussion of Unity Temple in Oak Park, IL (1906), where budgetary constraints and ideological intent dictated Wright develop a unique concrete aesthetic. ${ }^{6}$ Next, the Imperial Hotel in Tokyo, Japan (1913-22) was considered, followed by two of his California houses, Aline Barnsdall's Hollyhock House (Los Angeles, 1917) and Alice Millard's La Miniatura (Pasadena, 1923). ${ }^{7}$ For the latter example, a closer examination was made of Wright's own thoughts regarding the aesthetics of "that gutter rat," textured concrete block. After briefly noting Irving Gill's pioneering work in tilt-slab construction and Wright's son Lloyd's association with Gill, a more extensive evaluation began of Frank Lloyd Wright's use of concrete for the Kaufmann House, Fallingwater, near Mill Run, PA (1936-38). ${ }^{8}$ This included extensive period photographs of the initial construction, as well as those of the finished structure.

Students were asked for feedback on the presentation and the instructor exchange. Table 3 summarizes the student response to several questions regarding the presentation.

Student reactions were mixed to this presentation, with only medium scores concerning how much new information they learned about Fallingwater from this lecture. Two factors likely contributed to this. Since many students are from western Pennsylvania, several had previously visited Fallingwater providing an initial familiarity with the structure. A number also took advantage of Dr. Rose's extra credit assignment in CET 1112 and had quite recent knowledge of the structure and the repairs. Most found the presentation easy to follow, particularly those who 
did the extra credit assignment. Some felt an onsite field trip would have been more beneficial than just a visual presentation, while other students felt the classroom lecture "gave a new perspective on the structure other than just from an engineering point of view" and "put a face with all we learned about Fallingwater."

Table 3 Summary of student feedback regarding Dr. Grash's presentation in CET 1112

\begin{tabular}{|l|c|}
\hline \multicolumn{1}{|c|}{ Evaluation Statement } & $\begin{array}{c}\text { Average } \\
\text { Response }\end{array}$ \\
\hline $\begin{array}{l}\text { The amount I learned (that I already did not know) about Fallingwater from the } \\
\text { presentation was: } \\
\text { (1 none }-5 \text { significant) }\end{array}$ & 3.6 \\
\hline $\begin{array}{l}\text { The presentation was at the right level and easy to follow: } \\
\text { (1 strongly disagree }-5 \text { strongly agree) }\end{array}$ & 4.1 \\
\hline $\begin{array}{l}\text { The presentation gave me an appreciation of the role of aesthetics in the design } \\
\text { of Fallingwater and other structures: } \\
\text { (1 strongly disagree }-5 \text { strongly agree) }\end{array}$ & 3.9 \\
\hline $\begin{array}{l}\text { (Answer if you did the extra credit assignment in CET 1112) The extra credit } \\
\text { assignment helped me understand the presentation better: } \\
\text { (1 strongly disagree }-5 \text { strongly agree) }\end{array}$ & \\
\hline $\begin{array}{l}\text { I think it would be beneficial to have more opportunities for interdisciplinary } \\
\text { topics and guest speakers in this or other technical courses: } \\
\text { (1 strongly disagree }-5 \text { strongly agree) }\end{array}$ & 4.3 \\
\hline
\end{tabular}

CET 1113 Advanced Structures:

This course is an elective course for students specializing in structural engineering. This is primarily a structural analysis class, but about one-quarter of the class considers steel plate girders and composite beam design. In addition to structural analysis topics, students also learn to determine wind and snow loading for buildings. The course is three credits, meeting for one hour twice a week and for a three-hour recitation period each week. There were 13 students in this class and almost all of the students were also in the reinforced concrete design class.

For this class, Dr. Grash focused her presentation on "The Economics of Aesthetics: The Development of the Skyscraper in American Architecture." Essentially, this lecture intended to cover the structural and economic development of commercial high-rise buildings from the nineteenth through mid-twentieth centuries. The presentation began with discussion of the factors contributing to the rise of skyscrapers, including inventions such as the Otis safety elevator and the Bessemer converter process (which led to cost-effective commercial steel usage), as well as the desire for fireproof construction (after a number of major urban fires) and rising real estate costs in central business districts. Next, the pros and cons of wrought iron construction were considered against the structural, aesthetic and economic use of cast iron, followed by a detailed examination of the rather conservative historicism in form and ornamentation found in New York school skyscrapers such as Richard Morris Hunt's Tribune Building (1873-75; enlarged 1903-05) and George B. Post's World Building (1889-90). ${ }^{9}$

One of the major issues explored in this lecture was the role of aesthetics and corporate competition among high-rise buildings, and, following recent work by such scholars as Carol 
Willis, ${ }^{10}$ the equally important role that economics played in company headquarters and speculative ventures. Therefore, landmark New York structures such as Ernest Flagg's Singer Building (1906-08), Cass Gilbert's Woolworth Building (1911-13), and Ernest Graham's Equitable Building (1915) were examined. The latter's importance is particularly notable for its swamping of the New York real estate market and its impact on the 1916 zoning ordinance requiring setback designs. The impact of the 1871 Great Chicago Fire was also considered, and the more radical structural and aesthetic experimentation that occurred there, in works by William Le Baron Jenny (Home Insurance Building, 1883-86), Burnham and Root (Reliance Building, 1890-94), and Louis Sullivan (Wainwright Building, St. Louis, 1890-91). Two events in Chicago shaped skyscraper aesthetics in this era: the "White City" exploited in the 1893 World Columbian Exposition, and the 1922 Chicago Tribune Tower competition. The presentation concluded with an examination of William Van Alen's Chrysler Building (1928-30) and Shreve, Lamb and Harmon's Empire State Building (1929-31) set off against the development of the glass box skyscraper, epitomized by Howe and Lescaze's PSFS Building (Philadelphia, 1929-32) and Mies van der Rohe's Seagram Building (New York, 1954-58).

Student feedback on the presentation and the instructor exchange is summarized in Table 4.

Table 4 Summary of student feedback regarding Dr. Grash's presentation in CET 1113

\begin{tabular}{|l|c|}
\hline \multicolumn{1}{|c|}{ Evaluation Statement } & \multicolumn{1}{|c|}{$\begin{array}{c}\text { Average } \\
\text { Response }\end{array}$} \\
\hline $\begin{array}{l}\text { The amount I learned (that I already did not know) about the development of } \\
\text { the skyscraper was: } \\
\text { (1 nthing }-5 \text { significant) }\end{array}$ & 4.1 \\
\hline $\begin{array}{l}\text { The presentation was at the right level and easy to follow: } \\
\text { (1 strongly disagree }-5 \text { strongly agree) }\end{array}$ & 4.5 \\
\hline $\begin{array}{l}\text { The presentation gave me an appreciation of the role of aesthetics, corporate } \\
\text { competition and economics in the early design of skyscrapers: } \\
\text { (1 strongly disagree - 5 strongly agree) }\end{array}$ & 4.3 \\
\hline $\begin{array}{l}\text { I think it would be beneficial to have more opportunities for interdisciplinary } \\
\text { topics and guest speakers in this or other technical courses: } \\
\text { (1 strongly disagree }-5 \text { strongly agree) }\end{array}$ & \\
\hline
\end{tabular}

Although written student comments were sparse for this presentation, their evaluations indicated they learned a greater than average amount about the development of the skyscraper, and thought the presentation was at the right level and easy to follow. Additionally, they felt the lecture gave them an appreciation of the role of aesthetics, corporate competition and economics in the early design of skyscrapers. Students also encouraged the instructors to consider more opportunities for interdisciplinary topics and guest speakers in the future.

\section{Suggested Improvements and Advice on Seeking Opportunities for Collaboration}

Several improvements that might have heightened the experience discussed in this paper are being considered by the authors. Although the field trip was open to all students, it was not publicized well to the civil engineering technology students, and as a result, none took advantage of the opportunity. Encouraging students to attend the field trip may have improved the learning experience for the engineering students. For the fine arts class, incorporating a laboratory 
experience might be worthwhile. Mixing concrete followed by constructing and testing a concrete beam might provide improved appreciation of the nature of engineering design and analysis. Projects or assignments requiring students from the engineering course and the fine arts course to work together could also be used to further promote interaction, learning and shared perspectives. One possibility would be to have interdisciplinary student teams prepare a presentation on a skyscraper from both an artistic and engineering perspective.

The collaboration discussed in this paper resulted from the two instructors realizing the potential connection between their course topics and pursuing an opportunity to interact. For other engineering and engineering technology instructors interested in establishing such collaborations, the expertise and background of other faculty at their institution should be considered. It is easy to develop collaborations between structural engineering and fine arts faculty with expertise in architectural history. Fine arts and humanities faculty with other backgrounds may be more difficult to collaborate with. One engineering technology faculty member who teaches a course on leadership has collaborated with a humanities faculty to include analysis of films showing leadership in action. ${ }^{11}$ Collaboration between engineering and music faculty is also possible, when considering the science of musical instruments.

It is possible as well for engineering and engineering technology faculty to interact with faculty in fields other than the arts and humanities. Collaborations with economics and earth science faculty seem especially appropriate for certain engineering faculty members. Transportation engineering faculty might even pursue collaborations with sociology faculty to explore the dividing effect a transportation corridor might have on a community, or with a psychology faculty member collaborate to explore the habits of drivers in various situations. The key is to consider the expertise of the faculty at your institution and explore the opportunities for collaboration with them.

\section{Conclusion}

The collaboration between the two instructors provided engineering technology students an appreciation of the aesthetic aspects of the design of Fallingwater and skyscrapers and gave nonengineering students exposure to the technical aspects of reinforced concrete behavior and the repairs to Frank Lloyd Wright's Fallingwater. In both cases, students indicated the presentations made in their classes gave them a better appreciation of the perspectives of others on topics related to the course content. Students in the Frank Lloyd Wright class felt Dr. Rose's presentation was an excellent supplement to Dr. Grash's approach. The clear explanations and models helped students appreciate and understand the technical aspects of the design and repairs to Fallingwater. Students in Dr. Rose's reinforced concrete design class noted they gained an appreciation of the aesthetics involved in the design of Fallingater, the development of Frank Lloyd Wright as an architect and his relationship to the Kaufmanns during design and construction. In the advanced structures class, students observed the artistic components and corporate competitiveness illustrated in the early design of skyscrapers. This supplemented their learning of the technical aspects of structural analysis and design and hopefully has better prepared them for careers as professional engineers dealing with architects, owners and other design professionals. 


\section{Bibliography}

1. Technology Accreditation Commission, ABET, "Criteria for Accrediting Engineering Technology Programs Effective for Evaluations During 2004-2005 Accreditation Cycle." URL http://www.abet.org/criteria.html 2004-2005 TAC Criteria, accessed January 4, 2005.

2. American Society of Civil Engineers (2004). "Civil Engineering Body of Knowledge for the 21st Century: Preparing the Civil Engineer for the Future." January 12, 2004.

3. General Education Working Group, "Proposal for Phase One of General Education Curriculum," University of Pittsburgh at Johnstown, April 17, 2000.

4. Halford, B. "Engineering for Everyone," ASEE Prism, December 2004.

5. Grose, T.K. "Opening a New Book," ASEE Prism, February 2004.

6. Siry, J. Unity Temple: Frank Lloyd Wright and Architecture for Liberal Religion, Cambridge University Press, 1996.

7. Twombly, R. Frank Lloyd Wright: His Life and His Architecture, John Wiley, 1987.

8. Hoffmann, D. Frank Lloyd Wright's Fallingwater: The House and Its History, $2^{\text {nd }}$ ed revised, Dover, 1993.

9. Grash, V. "The Skyscraper" The Encyclopedia of Twentieth Century Architecture, R. Stephen Sennott, Editor, Fitzroy Dearborn, 2004, pp. 1214-1218.

10. Willis, C, Form Follows Finance: Skyscrapers and Skylines in New York and Chicago, Princeton Architectural Press, 1995.

11. Martinazzi, R. and Ward, D. "Teaching Leadership With 10,000 Words", Proceedings, 2004 ASEE Annual Conference, Salt Lake City.

ANDREW T. ROSE is an Assistant Professor of Civil Engineering Technology at the University of Pittsburgh at Johnstown (UPJ). Before joining the faculty at UPJ, he was a Staff Engineer with GAI Consultants in Pittsburgh. He holds a BS and MS in Civil Engineering from the University of Connecticut and Ph.D. from Virginia Tech. His teaching interests include soil mechanics, foundation design, structural steel design, structural analysis, and incorporating practical design experience into the undergraduate civil engineering technology curriculum. His research interests include soil behavior and behavior of laterally loaded transmission line foundations.

VALERIE GRASH is an Assistant Professor of Fine Arts in the Humanities Division at the University of Pittsburgh at Johnstown (UPJ). Prior to joining the faculty at UPJ, she taught at Point Park College in Pittsburgh, and worked for four years as an Architectural Interpretator and senior in-depth guide at Fallingwater. She holds a BA in History and English from Slippery Rock University, and MA and Ph.D. from Penn State University. Her research interests include the history of skyscraper development, specifically in Pittsburgh. 